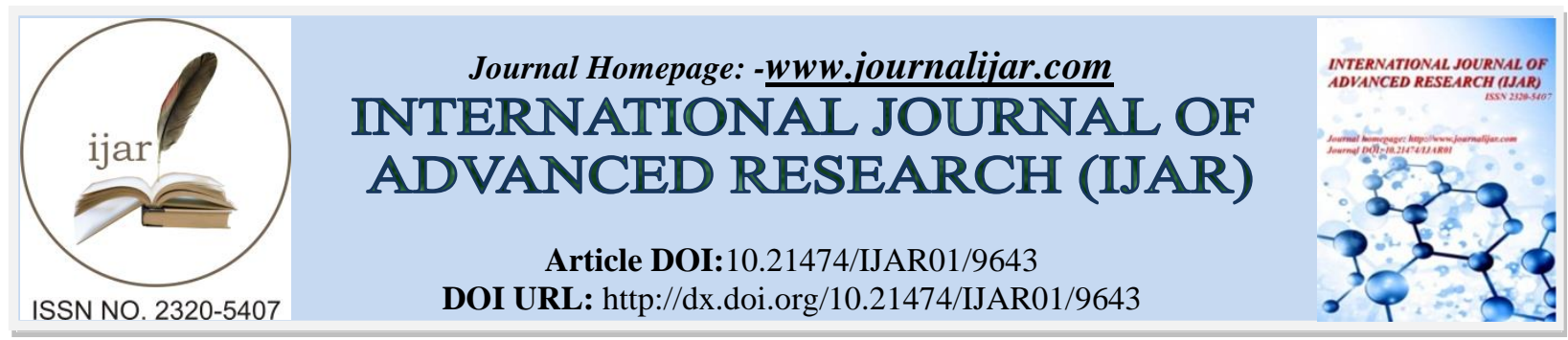

RESEARCH ARTICLE

\title{
REVIEW OF MEDICINALLY IMPORTANT PLANT SPECIES SARACA ASOCA (ROXB.)
}

\author{
S.S Yadav ${ }^{1}$, Ashwini A. Woo. ${ }^{2}$ and Kamlesh Choure ${ }^{2}$. \\ 1. State Forest Research Institute, Jabalpur Madhya Pradesh. \\ 2. AKS University SatanaMadhya Pradesh India.
}

\section{Manuscript Info}

Manuscript History

Received: 02 July 2019

Final Accepted: 04 August 2019

Published: September 2019

Key words:-

Genetic diversity, photochemical,

Saraca asoca, Pharmaceutical,

Molecular and Tissue culture.

\begin{abstract}
Saraca asoca is a relatively traded IUCN crimson listed tree species used in Ayurvedic drug treatments for the treatment of numerous disorders, especially gynecological troubles. However, information approximately the genetic variations among populations and corresponding variation in specialized metabolites of $S$. asoca stays uncertain. The presence of various antioxidant compounds including ascorbic acid, catechin, flavonoids, lignin glycosides, beta-sitosterol and its glucosidic identified in S. asoca leaf, bark and flower. The present study will provide basic information about distribution of Saraca asoca genotypes in India. Molecular characterization of Saraca asoca using molecular markers will be useful in the identification of diverse genotypes available in the country. Diverse genotypes and highly therapeutic compound may be used for future conservation and improvement program of Saraca asoca. Study has potential scope in the management of Saraca asoca species.
\end{abstract}

Copy Right, IJAR, 2019,. All rights reserved.

\section{Introduction:-}

Medicinal flora plays an important function in fitness care programs particularly in growing nations. Nowadays human beings have begun searching toward historical device of medication like Siddha, Ayurvedha and Unani. Since, they have got met with extreme obsession with the usage of modern-day medicinal machine. Medicinal flowers are bone of those historical structures of drugs. Quality and standardized medicinal plant life are vital for higher remedy with historic system of medication. Standardization manner may be performed via stepwise pharmacognostic studies. Pharmacological and phytochemical assessment performs a crucial function to recognize the underlying potency of crude drug. In order to make certain, the secure use of those drug treatments, a vital first step is the establishment of standards of first-class, protection and efficacy.

Plants were used for medicinal purposes long earlier than prehistoric period. Ayurveda, the traditional system of medication stay broadly practiced on many accounts. Population upward push, insufficient supply of drugs, prohibitive value of remedies, aspect consequences of several artificial capsules and development of resistance to presently used drugs for infectious illnesses have caused expanded emphasis on using plant fabric as a supply of drug treatments for a extensive form of human ailments. Ashoka is one the most historical and sacred tree of India. It is known by way of its binomial nomenclature Saraca asoca (Roxb.) De. Wilde (De Wilde, 1985) belonging to 
Caesalpinaceae subfamily of the legume. The IUCN (International Union for Conservation of Nature and Natural Resource) has listed endangered plant species found in the evergreen forests of India (Thakur et al. 1989).Asoka or Ashoka is the Sanskrit word meaning "Without sorrow."Ashoka is mainly sacred to the Hindu god of Love, Kamadeva, for whom it is worshipped each yr; it's far noted in Hindu mythology that the Indian truth seeker and founder of Buddhism, Gautama Siddhartha (c.563-483 B.C.) was stated to had been born beneath this tree (Pradhan et al. 2009). In mahakavya, or Indian epic poetry the Ashoka tree mentioned within the Ramayana in connection with the 'AshokaVatika', in which Hanuman first meets Sita. The Ashoka is a rain- wooded area tree. Its authentic distribution turned into inside the imperative areas of Deccan plateau, as well asthe middle section of the Western Ghats inside the western coastal area of the Indian subcontinent. The Ashoka is valued for its beautiful foliage and fragrant plants. The flowers being tons used for non secular ceremonies and temple decorations. It is a small, erect, evergreen tree, with deep green leaves growing in dense clusters. Its flowering season is around February to April. The Ashoka flowers are available in heavy, lush bunches. They are shiny orange yellow in coloration and will become red before they fall. In classical Ayurvedic textual content Ashokahas been referred to in vedanasthapanamahakashaya and Kashayaskandha by means of aacharya Charaka. Aacharya Sushruta covered Ashoka in Rodhradigana. As all of us recognize Ashoka is the drug of preference in Raktapradara (dysfunctional uterine bleeding) however this action of Ashoka turned into no longer mentioned in Ayurvedic textual content like Carakasamhita, Sushrutasamhita and in Nighantus.Vrundamadhava was the first who described use of ashoka in Raktapradara. Ashoka is the well-known drug for feminine disorders, inspite of those aacharyaSushruta has been referred to using Ashoka in Kalyanakalawana of Vatvyadhichikitsa, in Tilvakasarpi,Vranavachoornan, krushabhaagada, Dundubhiswaniya bankruptcy, in eye sickness (mainly pitta-kaphaj), in Mahakalyanakaghruta. Also aacharyaVagbhata has been noted the use of Ashokaghruta. Generally in exercise the bark of Ashoka is used for remedy. The bark is sour and acrid; refrigerant, astringent to the bowels, alexiteric, anthelmintic, demulcent, emollient; treatments dyspepsia, thirst, burning sensation, illnesses of the blood, biliousness, results of fatigue, tumors, enlargement of the stomach, colic, piles, ulcers, bloody discharges from the uterus, menorrhagia; useful in fractures of the bones; beautifies the complexion. The bark is an awful lot utilized in uterine affections and mainly in menorrhagia. The seeds are beneficial in urinary discharges (Kirtikar and Basu 1991).

\section{Habit and Habitat}

Saraca asoca is significantly discovered in Malayan Peninsula, Myanmar, Srilanka and Bangladesh. In India it is generally located in Khasi hills of Assam, hilly areas of West Bengal, Western Ghats of Maharashtra and Northern regions (Purohit and Vyas, 2004). Its original distribution was in valuable regions of Deccan Platue in addition to the significant components of Western Ghats in the Western coastal vicinity of the Indian Subcontinent (Preeti et al., 2012) also located in Andaman Islands (Kokate et al., 2003). The tree is determined in Central and Eastern Himalaya, Eastern Bengal, Western Peninsula, Burma and Malaysia (Ali, 2006). It is broadly allotted throughout Indian Subcontinent in evergreen forests as much as an elevation of about 750 meters. Its propagation is carried out by means of the seeds (Prajapati et al., 2003). The plant prefers moist and well-drained soil. Red laterite alluvial soil is seen exceedingly suitable for the boom of plant. It calls for an annual rainfall starting from 2000-4000 mm with a temperature of 35 to 40 degree Celsius. Deep and moist soil mainly close to water bodies choose top boom. It is at risk of frost and fire. Its coppicing potential is bad. It is a moderately shade loving tree. Mature seeds increase at the plant in the month of February to April, which might be gathered from the ground on falling. The seeds are soaked in water for twelve hours and sown on extended beds, seeds take about twenty days for germination. The plants that are 1/2 to 365 days vintage are used for subject planting. Application of Farm Yard Manure at $10 \mathrm{~kg} / \mathrm{tree} / \mathrm{year}$ is good for the increase of plant. The flora is to be irrigated in hot season. Tree is reducing at 20 years to take away the bark. It has to be performed at rainy season to sell sprouting (Purohit and Vyas, 2004).

\section{Vernacular names}

Sanskrit - Kankeli, Asoka; Gandhpushpa ; English - Asoka tree ; Hindi - Ashoka, Anganpriya ; Marathi- Ashoka ; Bengali - Ashoka, Oshok ; Gujrati - Asupala, AshopalavTelugu - Asok ; Tamil and Malayalam - Asogam ; Cannad Asokada, Kankelimara ; Panjabi - Ashok

\section{Traditional uses}

Ashoka has been primarily used as a traditional remedy for feminine issues, like Leucorrhoea, menorrhagia, dysfunctional uterine bleeding and so forth. Bark is stated to therapy biliousness, dyspepsia, dysentery, colic, piles, ulcers and zits. Leaves own blood purifying houses and their juice mixed with cumin seed is used for stomach-pain. Flowers are considered to be an awesome uterine tonic in addition to in biliousness and syphilis. In Assam culmination are chewed rather for areca-nuts. Pods are stated to make excellent forage for cattle. Wood is light, 
reddish, brown, smooth used for making ploughs and shafts in Assam and for house constructing cause in Ceylon. The seeds are useful in urinary discharges. The bark is tons used in uterine affections and particularly in menorrhagia. A decoction of the bark in milk is usually prescribed. According to aacharya Sushruta the bark, vegetation and fruits are prescribed in aggregate with other drugs for the treatment of Snake-chew and scorpionsting but Mhaskar and Caius has been concluded that the bark, flower and culmination are equally useless within the remedy of snake-chunk and scorpion-sting (Mollik et al. 2010).

Ashoka is likewise efficiently used in Ayurveda for clearing congestion from Medas and Mamsa Dhatus, particularly whilst there can be leucorrhoea, endometriosis, cysts and fibroids from excess kapha and ama in Artavasrotas. The ashoka herb also has a nourshing impact on the circulatory gadget, thereby making it a powerful remedy in arrhythmia and cardiac weak spot. The Ashoka herb advantages the endometrium and uterine muscle mass and this makes it effective as a uterine tonic for abnormal menstrual cycles and miscarriage. Ksheerapaka of 6 gm bark powder of Ashoka is usuful in Pradararoga of women; also this ksheerpaka is powerful in uterine inertia, uterine ache, urinary calculus, and dysuria. In pain neighborhood utility of paste of bark have to be effective. The womenfolk of Chhattisgarh boil the bark of Ashoka in cow"s milk, upload the sugar and devour it once a day for three days and repeat the identical after 3 months to prevent the gynecological disorders. On "Ashoka Shasthi day", in India married Hindu ladies consume the flower buds of Ashoka herbs to guard their child from grief and sorrow. The humans stricken by intellectual disease are cautioned to take bath underneath the shade of Ashok tree. For mental piece, the natives put together special „Herbal Mala' using root portions of Sita Ashok and supply it to the sufferers. The patients are counseled to put the powdered seeds within the Pan (Betel) and eat it empty belly. The healers put together decoction of the bark of Ashok is used for outside wash. In patients of Safed pani (leucorrhoea), the healers boil the bark in mixture of milk and water, after evaporation of water the aggregate is given to the sufferers (Biswas et al. 1972; Middelkoop and Labadie, 1986; Bhandary et al. 1995).

The precise analgesic houses present in Ashoka can used to calm the nerves once they have been aggravated through vatadosha. The ashoka herb is likewise powerful in purifying blood obviously and in preventing pores and skin hypersensitive reactions. This herb is also beneficial to enhance the complexion of the pores and skin (Kumar et al. 1980).

\section{Phytochemistry}

The Phytochemical take a look at shows the presence of numerous chemical ingredients of Saracaindica plant. Bark carries catechole, sterol, tannins, flavonoids, glycosides, leucopetargonidin and leucocyanidin (Yadav et al., 2013), (-) epicatechin, procyanidin p2, eleven'deoxyprocyanidin B, leucoperalgonidin and leucocyanidin. Dried bark incorporates 5 lignin glycosides, lyoniside, nudiposide, five-methoxy-9- $\beta-$ xylopyranosyl-(-) isolariciresinol, icariside E3 and schizandriside and three flavonoids epicatechin, epiafzelechin-( $4 \beta \rightarrow$ eight)-epicatechin and procyanidin B2, together with $\beta$-sitosterolglucoside (Pradhan et al., 2009). The bark additionally consists of 24methylcholest-5-3n-3B-ol, 24-ethylcholest-5, 22-dien-3B-ol and 24- ethylcholest-5n-3B-ol (Joshi, 2004). The bark extract includes gallic acid, beta guanine, indolylmethylglucosinolate, trimethylapigenin, tyramine, beta xanthine, gallic acid hexoside, hypophyllanthin, phloridzin, lignin, galloyl-isorhamnetin, myoinositol, cellotriose, 17Decarboxy betanin, lyoniside, procyanidingallate (Yadav et al., 2015). The wax obtained from bark includes nalkanes (C20-C35), esters (C34-C60) and primary alcohols (C20-C30) and n-octacasanol is also remoted (Joshi, 2004; Rangari, 2012; Yadav et al., 2013).

The stem includes quercetin, amyrine, ceryl alcohol and beta sterol. Bark and stem discovered to comprise quercetin, quercetin-3-O- $\alpha$-lrhamnoside, kaempferol three-O- $\alpha$ lhamnoside, amyrine, ceryl alcohol and $\beta$-sitosterol (Yadav et al., 2013).

Flower carries oleic, linoleic, palmitic and stearic acids, P-sitosterol, quercetin, kaempferol-3-O-P-D-glucoside, apigenin-7-O-p-D-glucoside, Pelargonidin-three, five- diglucoside, cyanidin-three, leucocyanidin and gallic acid (Yadav et al., 2013). Four anthrocyanin pigments are remoted from plant life; beta and alpha sitosterol are remoted from fixed oil of vegetation (Rastogi and Mehrotra, 1999). Seed and Pod incorporates oleic, linoleic, palmitic and stearic acids catechol, (-) epicatechol and leucocyanidin (Yadav et al., 2013).

\section{Biological and pharmacological properties of $S$. asoca}


The antique Ayurvedic texts blended with numerous ethno- botanical uses of this plant have stimulated numerous research organizations in India and somewhere else to systematically investigate its beneficial claims and take a look at any novel pharmaceutical residences that it could possess. Ethanobotanical, phytochemical and pharmacological properties have been reviewed recently by Kauser et al. (2016).

\section{Antibacterial}

Numerous literature reports establish the antibacterial homes of methanolic, ethnolic, acetone and aqueous extracts of bark, dried flower buds and leaves of S. asoca (Pal et al. 1985; Singh et al. 2009; Mathew et al. 2009; Sarojini et al. 2011; Shirolkar et al. 2013). These were tested in opposition to many pathogenic bacteria which includes Bacillus subtilis, Escherichia coli, Salmonella typhosa, S. Typhimurium, S. Typhii, S. Viballe- rup, S. Enteritis, Staphylococcus aureus, Bacillus cereus, Klebsiella pneumonia, K. Aerogenes, Shigellaboydis S. Sonnei, S. Flexneri, S. Dyserteriae, Pseudomonas aeruginosa, P. Vulgaris, Vibrocholerae, Proteus vulgaris, and so on. As such this plant is a seemingly treasured resource to discover single molecular antibiotics in the future in opposition to the backdrop of rising resistance of numerous human pathogenic micro organism to the acknowledged most important antibiotics.

\section{Antifungal}

Traditionally fungal infections have been attributed to compromised immune reaction of an individual and no longer posing a very serious chance to the population at large; however, there have been growing incidences of fungal disorder outbreaks inside the beyond. Finding new antifungal marketers is consequently a concern of the scientific microbiology (Dabur et al., 2007).

\section{Antimennorhagic, oxytocic and uterine tonic}

The use of $S$. asoca dried bark, root and plants to manipulate uterine abnormalities, menorrhagia (immoderate menstrual bleeding), ammenorhea, painful periods, endometrosis and issues of the menstrual cycle is widely known in India (Mollik et al. 2010; Pradhan et al. 2009; Khan et al. 1994; Begum et al. 2014). The root decoction of S. asoca is also fed on after transport for superior lochial discharge (Pradhan et al. 2009). Experiments have discovered the capability of bark aqueous extract to stimulate and loosen up the intestinal muscle, lengthen uterine contractions and additionally as a uterine sedative (Pradhan et al. 2009; Mishra et al. 2013). The uterine tonic software of the bark has been attributed to its effect on the endometrium and ovaries as an estrogenic stimulant (Mishra et al. 2013; Mitra et al. 1999). The ethanolic extract of the bark have been proven to be effective on the gravid uteri and the estrogen primed uteri (Pradhan et al. 2009). A phenolic glycoside P2 isolated from S. indica has been shown to produce oxytocic activity each in vitro and in vivo on the animal uteri and in vitro on human myometrial tubes (Satyavati et al. 1970).

\section{Anticancer}

Natural products have supplied a number of the most effective anticancer leads in the beyond, several already being into a success business production (Kusari et al. 2014). Ethnobotanical studies of S. asoca have found out its flavonoid fraction (from flora) to save you -degree pores and skin carcinogenesis and preferentially act towards Dalton's lymphoma ascites and Sarcoma-180 tumors cells, even as being non-poisonous to ordinary lymhpocytes (Cibin et al. 2012; Kaur, and Misra, 1980). The ethanolic extract of Ashoka was shown to inhibit breast most cancers (Yadav et al. 2015). The lectin 'saracin' remoted from the seed integument has been suggested to set off apoptosis in human T- lymphocytes in an in vitro assay (Ghosh et al. 1999).

\section{Anti-inflammatory, antiarthritic and cardioprotective effect}

Chronic arthritis and cardiovascular diseases are generally attributed to the inflammatory response mediated by seasoned-inflammatory cytokines. The extracts of the leaf, bark and root of $S$. asoca have been shown to show off anti inflammatory capability via notably inhibiting the binding of numerous transcription elements which includes NF- $\alpha$ B, AP-1, GATA-1, and many others. To their target DNA sequences, thereby lowering the degrees of seasoned- inflammatory cytokines (Saha et al. 2012). S. asoca extract has also been proven to lessen the levels of seasoned-inflammatory cytokines IL-1 and TNF- $\alpha$ (Cibin et al. 2012). Several reviews describe the anti- arthritic capability of $S$. asoca the usage of the version device of Carageenan-precipitated paw oedema and also brine shrimp assay (Pradhan et al. 2009; Mishra et al. 2013; Preeti et al. 2012; Shelar et al. 2010). Furthermore, S. asoca plant extracts had been proven to reduce the extent of liver and lysosomal enzymes, serum collagen and restoring of regular histologi- cal architecture of joints, thereby decreasing rheumatoid arthritis in rats (Saha et al. 2012). The ethanolic extract of S. indica has been pronounced as anti-inflammatory and additionally proven to defend cardiac 
tissue from infiltration of inflammatory cells (Swamy et al. 2013). S. asoca extracts are also recognized for his or her hemopurificatory results (Pradhan et al. 2009).

\title{
Antiulcer
}

The aqueous suspension extract of S. asoca flora, dried flower buds, bark and seeds have been shown to curtail ulcers in albino rats (Mishra et al. 2013; Preeti et al. 2012; Preethi and Krishnakumar, 2011; Saha et al. 2012). The effect of anti-ulcer the aqueous extract of S. indica flora became proven in albino rats by means of employing two models, particularly pyloric ligation and aspirin-precipitated gastric ulcer. In each these experiments, the quantity of gastric juice produced and the acidity and ulcer index were shown to be decreased re- markably as compared to the manipulate rats, when treated with the aqueous extract of S. indica (Ahmed, 2011; Maruthappan and Sakthi Shree, 2010). The antiulcerogenic effect of those extracts should likely be attributed to the presence of saponins, triterpenes, tannins, catechin, sterols, phenolic glycosides and flavonoids (Lakshmi et al. 2013; Ahmed, 2011). The molecules answerable for ulcer discount are concept to behave either by inhibition of basal gastric secretion and/or stimulation of mucus secretion and/or endogenous gastric mucosal secretions which can be precipitated through prostaglandin E2 and I2 synthesis, and/or antioxidant pastime of the flavonoids gift inside the aqueous extract of S. indica which counter the reactive oxidants present inside the gastrointestinal lumen (Mishra et al. 2013; Preeti et al. 2012; Lakshmi et al. 2013).

\section{Antioxidant, antidiabetic and hypolipidemic}

A quantity of stories have defined the presence of various antioxidant compounds which includes ascorbic acid, catechin, flavonoids, lignin glycosides, beta-sitosterol and its glucosidic form, polyphenolics along with gallic acid in chloroform and methanol extracts of S. asoca leaf, bark and flower (Saha et al. 2012; Jain et al. 2013; Samee and Vorarat, 2007; Panchawat and Sisodia, 2010; Pandey et al. 2011; Sadhu et al. 2007; Pal et al. 2014; Mir et al. 2012; Prathapan et al. 2012; Katiyar et al. 2013; Yadav et al. 2015). The flavonoid fraction of S. asoca flora and leaves has been shown to inhibit $\alpha$-glucosidase and $\alpha$ - amylase enzymes related to kind-2 diabetes and also prevent LDL (low density lipoprotein) oxidation (Jain et al. 2013; Prathapan et al. 2012; Kumar et al. 2012). These re- ports have additionally mentioned $S$. asoca extracts lower lipid and ldl cholesterol content and reduce the improved glucose levels in a dose-dependent way in streptozotocin-brought on dia- betic albino rats and mice (Jain et al. 2013; Kumar et al. 2012). They have also been stated to lessen the diabetes-caused renal oxidative strain. Application of this plant extract has additionally been proven to enhance pancreatic, renal and hepatic profiles in addition to the general fitness in diabetic mice (Kumar et al. 2012; Gahlaut et al. 2013; Khatoon et al. 2009).

\begin{abstract}
Analgesic
There is a wealth of facts at the analgesic effect of $S$. asoca in conventional remedy texts which has been verified through experiments that used methanolic, ethenolic and petro-leum ether, chloroform and aqueous extracts of the bark and leaves (Preeti et al. 2012; Saravanan et al. 2011; Verma et al. 2010). The analgesic belongings of S. indica has been attributed to its ability to inhibit sensory nerve stimulation, which changed into experimentally confirmed the use of 3 exceptional techniques, specifically tail immersion approach, tail flick approach and formalin caused pain approach (Preethi and Krishnakumar, 2011; Saha et al. 2012). Since inflammatory responses make contributions to the improvement of pain, the anti- inflammatory activity defined above might explain the analgesic effect of $S$. asoca for the duration of the past due section of ache development (Saha et al. 2012; Preeti et al. 2012; Saravanan et al. 2011; Swamy et al. 2013). Thus, it's miles assumed that $S$. asoca extracts typically relieve ache by using performing on both the central and peripheral worried structures (Verma et al. 2010).
\end{abstract}

\section{Anti-nephrolithiatic}

S. asoca root has been mentioned to be used in situations of urinary passage obstruction due to kidney stones and is known for its potency to dissolve oxalic acid stones present in the kidney (Pradhan et al. 2009; Begum et al. 2014; Godara et al. 2015).

\section{Central nervous system depressant and brain tonic}

Depression and tension are an increasing number of seemed as health risks. Central frightened machine (CNS) depressant interest of $S$. asoca leaves has been found out through the methanolic extracts which confirmed most CNS depressant interest in albino mice (Pradhan et al. 2009; Verma et al. 2012). The identical extracts have been stated to reduce the onset of sleep. They additionally prolonged the dura- tion of sleep brought on by using pentobarbitone. Additionally, they resulted in the decreased locomotor activity in mice (Verma et al. 2012). The mechanism of the depressant pastime can be related to the activation of $\alpha$-aminobutyric acid (GABA) receptors in 
the CNS through glycosides, flavonoids, saponins and tannins present in the plant extract, which culminates in anxiolysis, muscle rest and sedation (Verma et al. 2012; Yadav et al. 2013).

\section{Dermatoprotective}

The root, bark and seed extracts of $S$. asoca find several uses inside the remedy of skin complications including eczema, psoriasis, zits, dermatitis, herpes kushta/visarpa, pruritis, scabies, tinea pedis and pores and skin most cancers (Cibin et al. 2012; Kapoor, 2001). The flower extracts of S. asoca which includes flavonoids, has been proven to reduce skin tumours caused through 7,12-dimethyl benzanthracene (Cibin et al. 2012). It is likewise recognized to rejuvenate pores and skin complexion, induce short recovery of pores and skin in- juries, lessen freckles and external inflammations of the skin (Pradhan et al. 2009). Seed extracts were mentioned to be powerful against dermatophytic fungi (Pradhan et al. 2009).

\section{Larvicidal}

Combating the risk of bugs consisting of mosquitoes is the important precedence within the warfare towards communicable diseases including malaria, dengue, filariasis, and so forth. The petroleum ether and chloroform extracts of the bark, leaves and float- ers of S. indica were proven to significantly reduce the population of the mosquito Culexquinquefasciatus (Mishra et al. 2013; Mathew et al. 2009), thereby controlling the breeding of insect vectors.

\section{Anti-helminthic}

Presence of parasitic worms in the human frame ends in malnutrition, weak spot and susceptibility to bacterial and viral infections. Methanolic extracts of $S$. asoca leaves were reported to paralyze and kill the adult Indian earthworm, Pheritimaposthuma which resembles the human round-malicious program parasite (Preeti et al. 2012; Sarojini et al. 2011).

\section{Antimutagenic and genoprotective effect}

Mutagenesis by using any source can motive cancer and other debilitating diseases. $S$. asoca has been called a very good source of antioxidants that could reduce mutagenesis. Recently, S. asoca bark extract has been reported to save you mutagenesis in Salmonella strains (Nag et al. 2013). This extract had additionally been shown to guard Swiss albino mice towards cyc- lophosphamide-precipitated genotoxicity (Mukherjee et al. 2012). Interestingly, a lignin glycoside 'saracoside' isolated from S.asoca stem bark has been reported as a robust inhibitor of DNA topoisomerase IB, an vital enzyme worried in lots of methods wherein DNA unwinding is vital together with replication, transcription, recombination, etc (Nag et al. 2013; Mukherjee et al. 2012).

\section{Other medicinal uses}

Dried root of $S$. asoca has been pronounced to be useful in paralysis, hemiplegia and visceral numbness showing its effect through the parasympathetic and independent frightened systems (Pradhan et al. 2009). The extracts of S. asoca seeds and dried plant life have shown homes of being an osteoid tissue promoter along with in treatment of rickets, behind schedule bone consolidation and calcium deficiency (Pradhan et al. 2009; Kapoor, 2001; Nadakarni, 1957). Antipyretic motion of methanolic extracts of S. ascoa leaves has been these days mentioned (Varaprasad et al. 2011; Sasmal et al. 2012). Similarly, many other biological/ pharmacological moves of its diverse extracts had been mentioned consisting of an antidote in snake chunk, an anti- leucorrhea agent, a contraceptive, and within the treatment of dysentery, malicious program infestations and belly ache (Kapoor, 2001).

Table 1:-Various phytochemical compounds present in different organs of Saraca asoca

\begin{tabular}{|c|c|c|c|c|}
\hline Compound & $\begin{array}{l}\text { Class of } \\
\text { compound }\end{array}$ & $\begin{array}{l}\text { Plant } \\
\text { organ }\end{array}$ & Activity & References \\
\hline Acetyl salicylic acid & $\begin{array}{l}\text { Phenolic } \\
\text { acid }\end{array}$ & Seed & Analgesic & Gupta et al. 2014 \\
\hline Gallic acid & $\begin{array}{l}\text { Phenolic } \\
\text { acid }\end{array}$ & $\begin{array}{l}\text { Leaves, } \\
\text { Bark, } \\
\text { flowers }\end{array}$ & $\begin{array}{l}\text { Hypolipidemic, } \\
\text { antioxidant }\end{array}$ & Pradhan et al. 2009 \\
\hline Ellagic acid & $\begin{array}{l}\text { Phenolic } \\
\text { acid }\end{array}$ & $\begin{array}{l}\text { Leaves, } \\
\text { Bark, } \\
\text { flowers }\end{array}$ & Antioxidant & Saha et al. 2013 \\
\hline
\end{tabular}




\begin{tabular}{|c|c|c|c|c|}
\hline Quercetin & $\begin{array}{l}\text { Phenolic } \\
\text { acid }\end{array}$ & $\begin{array}{l}\text { Leaves, } \\
\text { Bark, } \\
\text { flowers }\end{array}$ & Antioxidant & $\begin{array}{l}\text { Pradhan et al. 2009; Saha } \\
\text { et al. } 2013\end{array}$ \\
\hline Leucocyanidin & Flavonol & $\begin{array}{l}\text { Seed, pod, } \\
\text { bark }\end{array}$ & Anti-inflammatory & $\begin{array}{l}\text { Kalakotla et al. 2014; } \\
\text { Ahmad et al. } 2015\end{array}$ \\
\hline Leucopelargonidin & Flavonol & $\begin{array}{l}\text { Bark, } \\
\text { leaves }\end{array}$ & Anti-inflammatory & $\begin{array}{l}\text { Kalakotla et al. 2014; } \\
\text { Ahmad et al. } 2015\end{array}$ \\
\hline Benzene-1,2-diol & Catechin & $\begin{array}{l}\text { Seed, pod, } \\
\text { bark }\end{array}$ & $\begin{array}{l}\text { Anti-inflammatory, } \\
\text { antimicrobial }\end{array}$ & $\begin{array}{l}\text { Kalakotla et al. 2014; } \\
\text { Ahmad et al. } 2015\end{array}$ \\
\hline Epicatechin & Flavonol & $\begin{array}{l}\text { Seed, pod, } \\
\text { bark }\end{array}$ & $\begin{array}{l}\text { Anti-inflammatory, } \\
\text { antioxidant, }\end{array}$ & $\begin{array}{l}\text { Sadhu et al. 2007; } \\
\text { Shirolkar et al. } 2013\end{array}$ \\
\hline $\begin{array}{l}3 \square, 5 \text {-Dimethoxy } \\
\text { epicatechin }\end{array}$ & Flavonol & Bark & $\begin{array}{l}\text { Anti-inflammatory, } \\
\text { antimicrobial }\end{array}$ & Ahmad et al. 2015 \\
\hline Procyanidin B2 & Flavonol & Bark & Antioxidant & Sadhu et al. 2007 \\
\hline Gallocatechin & Flavonol & Bark & Anti-inflammatory & Ahmad et al. 2015 \\
\hline Epigallocatechin & Flavonol & Bark & $\begin{array}{l}\text { Anti-inflammatory, } \\
\text { antimicrobial }\end{array}$ & $\begin{array}{l}\text { Shirolkar et al. 2013; } \\
\text { Ahmad et al. } 2015\end{array}$ \\
\hline Haematoxylin & Flavonol & Bark & $\begin{array}{l}\text { Diagnostic purpose } \\
\text { (staining of tissues) }\end{array}$ & Gupta et al. 2014 \\
\hline $\begin{array}{l}\text { Quercetin-3-O-P-D- } \\
\text { glucoside }\end{array}$ & $\begin{array}{l}\text { Flavonol } \\
\text { glycoside }\end{array}$ & Flowers & Antioxidant & Pradhan et al. 2009 \\
\hline $\begin{array}{l}\text { Pelargonidin-3,5- } \\
\text { diglucoside }\end{array}$ & $\begin{array}{l}\text { Flavonol } \\
\text { glycoside }\end{array}$ & Flowers & $\begin{array}{l}\text { Antidiabetic, anti- } \\
\text { cataract }\end{array}$ & Somani and Sathaye, 2015 \\
\hline $\begin{array}{l}\text { Cyanidin-3,5- } \\
\text { diglucoside }\end{array}$ & $\begin{array}{l}\text { Flavonol } \\
\text { glycoside }\end{array}$ & Flowers & Antidiabetic & Somani and Sathaye, 2015 \\
\hline Lyoniside & $\begin{array}{l}\text { Lignan } \\
\text { glycoside }\end{array}$ & $\begin{array}{l}\text { Leaves, } \\
\text { Bark, } \\
\text { flowers }\end{array}$ & Antioxidant & $\begin{array}{l}\text { Panchawatand Sisodia, } \\
\text { 2010, Sadhu et al. } 2007\end{array}$ \\
\hline Nudiposide & $\begin{array}{l}\text { Lignan } \\
\text { glycoside }\end{array}$ & Bark & Antioxidant & $\begin{array}{l}\text { Panchawatand Sisodia, } \\
\text { 2010, Sadhu et al. } 2007\end{array}$ \\
\hline $\begin{array}{l}\text { 5-Methoxy-9-D- } \\
\text { xylopyranosyl }\end{array}$ & $\begin{array}{l}\text { Lignan } \\
\text { glycoside }\end{array}$ & Bark & Antioxidant & $\begin{array}{l}\text { Panchawatand Sisodia, } \\
\text { 2010, Sadhu et al. } 2007\end{array}$ \\
\hline Icariside E3 & $\begin{array}{l}\text { Lignan } \\
\text { glycoside }\end{array}$ & Bark & Antioxidant & $\begin{array}{l}\text { Panchawatand Sisodia, } \\
\text { 2010, Sadhu et al. } 2007\end{array}$ \\
\hline Schizandriside & $\begin{array}{l}\text { Lignan } \\
\text { glycoside }\end{array}$ & Bark & Antioxidant & $\begin{array}{l}\text { Panchawatand Sisodia, } \\
\text { 2010, Sadhu et al. } 2007\end{array}$ \\
\hline Sitosterol & Sterol & $\begin{array}{l}\text { Stem, } \\
\text { Bark, } \\
\text { leaves, }\end{array}$ & $\begin{array}{l}\text { Hypolipidemic, } \\
\text { antioxidant, }\end{array}$ & $\begin{array}{l}\text { Mishra et al. 2013; Pandey } \\
\text { et al. } 2011\end{array}$ \\
\hline Sitosterol glucoside & $\begin{array}{l}\text { Steroidal } \\
\text { glycoside }\end{array}$ & $\begin{array}{l}\text { Bark, } \\
\text { leaves }\end{array}$ & $\begin{array}{l}\text { Hypolipidemic, } \\
\text { antioxidant, }\end{array}$ & $\begin{array}{l}\text { Pradhan et al. 2009; } \\
\text { Mishra et al. } 2013\end{array}$ \\
\hline Oleic acid & Fatty acid & Pod, Seed & $\begin{array}{l}\text { Anti-inflammatory, } \\
\text { cardioprotective }\end{array}$ & Kalakotla et al. 2014 \\
\hline Linoleic acid & Fatty acid & Pod, Seed & $\begin{array}{l}\text { Anti-inflammatory, } \\
\text { cardioprotective }\end{array}$ & Kalakotla et al. 2014 \\
\hline
\end{tabular}

Biotechnological approaches towards improvement of Saraca asoca Genetic diversity

Genetic studies pronounced in $S$. asoca were specifically limited to resolving identification troubles in crude pills (Urumarudappa et al., 2016; Hegde et al., 2018). However, genetic markers had been used in different research 
works to evaluate versions, relationships and population genetic parameters in S. asoca (Sumangala et al., 2016). Many phytochemical studies have been performed for the evaluation of various compounds in $S$. asoca as (+)catechin, (-)-epicatechin, procyanidine B-2, eleven- deoxyprocyanidin B4, leucocyanidin and so on (Shirolkar et al., 2013; Singh et al., 2015). Catechins were said for numerous biological sports and are beneficial in symptomatic treatment of many gastrointestinal, respiratory and vascular problems (Mittal et al., 2013). This has brought about overexploitation of the species. The plant is labeled as 'prone' by means of International Union for Conservation of Nature (IUCN). Sumangala et al. (2017) stated domestic call for of 'Ashoka' bark to be $>15,000$ metric tonnes in India. The fragmented population is inadequate to fulfil business demand, attracting adulteration (Hegde et al., 2017). Therefore, protection of this species will become a need to save you its extinction. Variation in plant population is normally assessed the usage of phytochemical and genetic marker systems (Schlag and McIntosh, 2013; Younsi et al., 2018). Individual technique based on molecular marker has advantages and disadvantages. However, maximum of them are crucially dependent on the genetic adjustments taking place through the years due to mutation strategies. While, entire-genome based totally sequencing might offer the first-class photograph at the genetic make-up of a plant, limited availability of assets and exorbitant fees has made its use extraordinarily restricted to this point. Among cost potent techniques e.g., Inter Simple Sequence Repeat (ISSR) assays are independent from environmental impacts, smooth to carry out and are moderately touchy and simple and therefore extensively used for molecular diversity analysis.

During phytochemical investigations the usage of High Performance Liquid Chromatographic (HPLC) approach has however, remained the only, correct, short and prime preference of the researchers through the years (Pai et al., 2011; Pawar et al., 2011). Analysis of phytochemical range helps to apprehend the specialised metabolite compositions and to expand great manage parameters, in view that it's far a well hooked up reality that medicinal plants amassed at special instances and from exclusive localities may extensively differ in their kinds and quantities of phytochemical compositions. Since the expression of genetic records isn't always always assured, assessment of the volume of variant of phytoconstitutents alongside their genetic characters might add value and offer robust facts for development of techniques for conservation, sustainable usage, and for selection of elite clones for industrial utilization (Schlag and McIntosh, 2013).

Molecular marker primarily based methods are critical in genetic range analysis. The improvement and utilization of molecular markers for the exploitation and identity of plant genetic range is one of the most key developments inside the field of molecular genetics research. Various kinds of techniques are used to estimate genetic diversity together with dominant markers (Random Amplified Polymorphic DNA (RAPD), DNA amplification fingerprinting (DAF), Arbitrarily primed polymerase chain reaction (APPCR), Inter-simple collection repeat (ISSR) and Amplified Fragment Length Polymorphism (AFLP), and co-dominant markers (Restriction Fragment Length Polymorphism (RFLP), Simple sequence repeats (SSRs), Sequence characterized amplified regions (SCARs), Cleaved amplified polymorphic sequence (CAPS), Expressed sequence tags (ESTs), Single Nucleotide Polymorphisms (SNPs) and collection tagged web sites (STSs). Today, new techniques are frequently being developed. No such techniques are ideal but these satisfy all necessities needed by means of plant researchers. Each technique has its personal advantages and boundaries.

RAPD evaluation of the $S$. asoca populations discovered exceptionally variable diagnosed markers. It become taken up with three fluorescent-categorized RAPD primers through a high velocity automated DNA fragment analysis tool based upon the automated fluorescent DNA sequencer with the molecular taxonomy software program (Mohan et al. 2017). Higher level of genetic diversity was found amongst studied genotypes. In a current observe, RAPDS markers were applied for DNA fingerprinting and the population genetic shape of 7 wild and three cultivated populations totaling a hundred and sixty individuals of $S$. asoca in the Western Ghats location of Karnataka, Maharashtra and Goa for evaluation (Saini et al. 2018). The examine showed that big stage of genetic variety existing in herbal populations of $S$. asoca, suggesting true natural pass-pollination, giving encouraging indicators that the gene pool is below no immediately chance. Any conservation approach ought to utilize the determined genetic variant in the preference of planting inventory for programmes of conservation, propagation and reforestation.

Saraca asoca is a relatively traded IUCN crimson listed tree species used in Ayurvedic drug treatments for the treatment of numerous disorders, especially gynaecological troubles. However, information approximately the genetic variations among populations and corresponding variation in specialised metabolites of $S$. asoca stays uncertain. To address this issue, 11 populations of S. asoca with 106 accessions gathered from Western Ghats of 
India had been analyzed the use of ISSR Rmarkers along side decided on phytocompounds the usage of RP-HPLC (Hedge et al. 2018). Twenty primers were screened, out of which seven have been decided on for in addition evaluation based totally on technology of clean polymorphic banding patterns. These seven ISSR primers produced seventy four polymorphic loci. AMOVA showed $43 \%$ genetic variant inside populations and fifty seven $\%$ most of the populations of $S$. asoca. According to UPGMA clustering and Bayesian Models two clusters of comparable grouping styles were constructed. Dissimilarity analysis showed close affiliation of genotypes in step with their geographical locations.

In a take a look at conducted on improvement of microsatellite markers in $S$. asoca a complete of 15 microsatellite primer pairs have been synthesized and screened for polymorphism (Sumangala et al. 2013). After initial screening of the 15 primers, 10 primer pairs that confirmed polymorphism have been retained for in addition analysis. Six of these loci have been di-nucleotide repeats, one each had been mononucleotide and tri-nucleotide repeats and two were penta-nucleotide repeat. The microsatellite markers pronounced on this study are helpful for researchers to look at populace genetic shape of the species to formulate sound conservation and control programmes.

Table 2:-Applications of molecular markers in Saraca asoca for diversity analysis

\begin{tabular}{|l|l|l|}
\hline Marker & Purpose & Reference \\
\hline SSR & Polymorphism analysis & Sumangala et al. 2013 \\
\hline Fluorescent-labeled RAPD & Genetic diversity analysis & Mohan et al. 2017 \\
\hline ISSR & Genetic variation analysis & Hedge et al. 2018 \\
\hline RAPD & Population genetic structure & Saini et al. 2018 \\
\hline
\end{tabular}

\section{Tissue culture}

Tissue culture techniques were implemented in S. asoca. In a have a look at (Shirin et al. 2015) four nutrient media [MS (Murashige and Skoog Medium), WPM (Woody Plant Medium), B5 (Gamborg's Medium) and NN (Nitsch and Nitsch Medium, 1969)] and five doses of BA (N6-Benzyladenine) $(0,2.2,4.4,8.8$ and $17.8 \mu \mathrm{M})$ and their all possible interactions were tested for shoot induction and proliferation from nodal segments of 3-yr-old plant life. B5 medium supplemented with $2.2 \mu \mathrm{M}$ BA changed into screened out because the most suitable medium shoot induction, proliferation and elongation of regenerated shoots. In order to beautify shoot quantity, the nitrogen supply in $\mathrm{B} 5$ medium become modified and 5 strengths of $\mathrm{KNO}_{3}$ were tested. The exclusive strengths of $\mathrm{KNO}_{3}(\mathrm{Potassium}$ nitrate) had statistically sizeable effect on quantity of shoots and on $0.25 \times$ energy of $\mathrm{KNO}_{3}$, maximum number of shoots (1.92) were acquired. The changed strengths of $\mathrm{KNO}_{3}$ did now not extensively affect the elongation of shoots. Effect of 5 durations (short dip, switch of shoots after 1 day, after three days, after five days and after 7 days) of pulse remedy with two hundred $\mu \mathrm{M}$ IBA (Indole-three-butyric acid) in half power MS liquid medium become tested. Thereafter, the shoots had been transferred to semi-stable half energy MS medium supplemented with zero. 2 $\mu \mathrm{M}$ IBA and 3.Ninety six $\mu$ Mphloroglucinol. Pulse remedy of five days period ended in $37.5 \%$ in vitro rooting of shoots. Plantlets had been hardened in soilrite soaked with half of power MS medium in subculture room and later shifted to a soil combination in color residence.

Further, callus induction studies have been attempted in S. asoca the usage of eleven explants viz., meristematic shoot tip, nodal section, internodal segment, leaf bits, axillary bud, cotyledon, embryo, seed, anther, ovary and hypocotyl from 5 special genotypes in 3 distinctive media viz., MS medium, B5 medium and WPM medium with 2,4-D at one-of-a-kind concentrations ( 0.5 to $4 . Z$ ero $\mathrm{mg} / \mathrm{l})$. Genotype four gathered from Periyakulam, explant ovary and the remedy $4(\mathrm{MS}+2$, four-D $2.0 \mathrm{mg} / \mathrm{l})$ spoke back first-class for callus induction (Paranthaman et al. 2017).

\section{Conclusions and future prospects:-}

Saraca asoca is an important medicinal plant species which has limited potential pockets in India. The present study will provide basic information about distribution of Saraca asoca genotypes in India. Molecular characterization of Saraca asoca using molecular markers will be useful in the identification of diverse genotypes available in the country. Diverse genotypes may be used for future conservation and improvement program of Saraca asoca. Genetic diversity analysis has potential scope in the management of a particular genotype or species. Beneficial genes can be identified to develop a gene construct for future genetic transformation of Saraca asoca genotypes. Identified genes may be correlated with higher level of any therapeutic compound available in Saraca asoca genotypes. Molecular characterization is helpful in the identification and selection of superior genotype on the basis 
of their geographical location. The present study will provide a platform for future research on Saraca asoca genotypes.

\section{Bibliography:-}

1. Ahmad, F., Misra, L., Tewari, R., Gupta, P., Mishra, P. and Shukla, R., Anti-inflammatory flavonol glycosides from Saraca asoca bark. Nat. Prod. Res., 2015, 23, 1-4.

2. Ahmed, C. Y., A study on the antiarthritic and antiulcer activities of Saraca indica Bark in rats and mice. Thesis, Department of Pharmacology, V. L. College of Pharmacy, Raichur, Karnataka, India. Abstr., 2011, page xiv. Discussion; pp. 147-148.

3. Ali M., Text book of Pharmacognosy. $2^{\text {nd }}$ ed., CBS Publishers and Distributors, New Delhi, 2006, $371-372$.

4. Begum, S. N., Ravikumar, K. and Ved, D. K., 'Asoka' - an important medicinal plant, its market scenario and conservation measures in India. Curr. Sci., 2014, 107, 26-28.

5. Bhandary, M. J., Chandrasekhar, K. R. and Kaveriappa, K. M., Medical ethnobotany of the Siddis of Uttara Kannada District, Karnataka, India. J. Ethnopharmacol., 1995, 47, 149-158.

6. Biswas, T. K. and Debnath, P., Asoka (Saracaindica Linn) - a cultural and scientific evaluation. Indian J. Hist. Sci., 1972, 7, 99-114.

7. Cibin, T. R., Devi, D. G. and Abraham, A., Chemoprevention of two-stage skin cancer in vivo by Saraca asoca. Integr. Cancer. Ther., 2012, 11, 279-286.

8. Dabur, R., Gupta, A., Mandal, T. K., Singh, D. D., Bajpai, V., Gurav, A. M. and Lavekar, G. S., Antimicrobial activity of some Indian medicinal plants. Afr. J. Trad. CAM, 2007, 4, 313-318.

9. De Wilde, W. J. J. O., Saraca tubiflora, a new species from west- central Sumatra (Caesalpinioideae). Blumea, 1985, 30,425-428.

10. Gahlaut, A., Shirolkar, A., Hooda, V. and Dabur, R., $\square$-sitosterol in different parts of Saraca asoca and herbal drug ashokarista: quali-quantitative analysis by liquid chromatography-mass spec- trometry. J. Adv. Pharm. Technol. Res., 2013, 4, 146-150.

11. Ghosh, S., Majumder, M., Majumder, S., Ganguly, N. K. and Chatterjee, B. P., Saracin: a lectin from Saraca indica seed integument induces apoptosis in human T-lymphocytes. Arch. Biochem. Biophys., 1999, 371, 163168.

12. Godara, D., Kaushik, V., Sharma, G. and Saini, V., A method of isolation of Capparisterol from Capparis decidua and antinephro- lithiasis activity. Am. J. Adv. Drug. Del., 2015, 3, 86-94.

13. Gupta, M., Sasmal, S. and Mukherjee, A., Therapeutic effects of acetone extract of Saraca asoca seeds on rats with adjuvant- induced arthritis via attenuating inflammatory responses. ISRN Rheumatol., 2014, 2004, pp. 112.

14. Hegde, S., Pai, S. R., Bhagwat, R. M., Saini, A., Rathore, P. K., Jalalpure, S. S., Hegde, H. V., Sugunan, A. P., Gupta, V. S., Kholkute S. D. and Roy, S., Genetic and phytochemical investigations for understanding population variability of the medicinally important tree Saraca asoca to help develop conservation strategies. Phytochemistry, 2018, 156, 43-54.

15. Jain, A., Jasmine, Sharma, S. and Saini, V., Hypolipidemic, hypoglycemic and antioxidant potential of Saraca asoca ethnolic leaves extract in streptozotocin induced-experimental diabetes. Int. J. Pharm. Pharm. Sciences, 2013, 5, 302-305.

16. Joshi, S. G. Medicinal Plants, Oxford and IBH Publishing Co Pvt LTD, 2004, 123-124.

17. Kalakotla, S., Mohan, G. K., Rani, M. S., Divya, L. and Pravallika, P. L., Screening of Saraca indica (Linn.) medicinal plant for antidiabetic and antioxidant activity. Der. Pharm. Lett., 2014, 6, 227-233.

18. Kapoor, L. D., Handbook of Ayurvedic Medicinal Plants, 2001, 1st edn, p. 298.

19. Katiyar, S., Patidar, D., Gupta, S., Singh, R. K. and Singh, P., Some Indian traditional medicinal plants with antioxidant activ- ity: a review. Int. J. Innovat. Res. Sci. Eng. Technol., 2013, 2, 7303-7314.

20. Kaur, J. D. and Misra, K., Biological and pharmacological activ- ity of Saraca asoca: anticancer activity. J. Indian Chem. Soc., 1980, 57(12), 1243.

21. Kauser, A. S., Hasan, A., Parrey, S. A. and Ahmad, W., Ethnobotanical, Phytochemical and Pharmacological Properties of Saraca asoca Bark: A Review. European J. Pharmaceut. Med. Res., 2016, 3, 274-279

22. Khan, M. A., Khan, T. and Ahmad, Z., Barks used as source of medicine in Madhya Pradesh, India. Fitoterapia, 1994, 65, 444- 446.

23. Khatoon, S., Singh, N., Kumar, S., Srivastava, N., Rathi, A. and Mehrotra, S., Authentication and quality evaluation of an important Ayurvedic drug - Ashoka bark. J. Sci. Ind. Res., 2009, 68, 393-400.

24. Kirtikar, K. R. and Basu, B. D., Indian Medicinal Plants. $2^{\text {nd }}$ ed., Bishen Singh Mahendra Pal Singh, Dehradun, 1991, 883-884. 
25. Kokate, C. K., Gokhale, A. S. and Gokhale, S. B., Cultivation of Medicinal Plants. $1^{\text {st }}$ ed., Nirali Prakashan, Pune, 2003, 7, 36-37.

26. Kumar, S., Narwal, S., Kumar, D., Singh, G., Narwal, S. and Arya, R., Evaluation of antihyperglycemic and antioxidant activi- ties of Saraca asoca (Roxb.) De Wild leaves in streptozotocin induced diabetic mice. Asian Pac. J. Trop. Med., 2012, 1, 170- 176.

27. Kumar, Y., Haridasan, K. and Rao, R. R., Ethnobotanical notes on certain medicinal plants among some Garo people around Balphakram Sanctuary in Meghalaya. Bull. Bot. Surv. India, 1980, 22, 161-165.

28. Kusari S., Singh S., Jayabaskaran C. (2014b). Rethinking production of Taxol(R) (paclitaxel) using endophyte biotechnology. Trends Biotechnol. 32, 304-311.

29. Lakshmi, K. N. V. C., Madhuri, M., Anwar, S., Ali, L., Bhimava- rapu, P. and Shaik, A., Evaluation of antiulcerogenic activity of various extracts of Saraca indica bark on aspirin induced gastric ulcers in albino rats. Int. J. Res. Pharm. Chem., 2013, 3, 753-758.

30. Maruthappan, V. and Sakthi Shree, K.,.Antiulcer activity of aqueous suspension of Saraca indica flower against gastric ulcers in albino rats. J. Pharm. Res., 2010, 3(1), 17.

31. Mathew, N., Anitha, M. G., Bala, T. S. L., Sivakumar, S. M., Narmadha, R. and Kalyanasundaram, M., Larvicidal activity of Saraca indica, Nyctanthes arbor-tristis, and Clitoriaternatea extracts against three mosquito vector species. Parasitol. Res., 2009, 104, 1017-1025.

32. Middelkoop, T. B. and Labadie, R. P., Int. J. Crude Drug Rec., 1986, 24, 41-44.

33. Mir, M. A., Sawhney, S. S. and Kumar, S., Comparative study upon the antioxidant potential of Saraca indica and Pterospermumacerifolium. J. Chem. Pharm. Res., 2012, 4, 4716-4720.

34. Mishra, A., Kumar, A., Rajbhar, N. and Kumar, A., Phytochemical and pharmacological importance of Saraca indica. Int. J. Pharm. Chem. Sci., 2013, 2, 1009-1013.

35. Mitra, S. K., Gopumadhavan, S., Venkataranganna, M. V., Sarma, D. N. K. and Anturlikar, S. D., Uterine tonic activity of U-3107 (EveCare), a herbal preparation in rats. Indian J. Pharm., 1999, 31, $200-203$.

36. Mittal, A., Kadyan, P., Gahlaut, A. and Dabur, R., Nontargeted identification of the phenolic and other compounds of Saraca asoca by high performance liquid chromatography-positive electrospray ionization and quadrupole time-of-flight mass spectrometry. ISRN Pharm., 2013, 1-10.

37. Mohan, C., Reddy, M. S., Kumar, S. M., Manzelat, S. F. and Cherku, P. D., RAPD studies of Saraca asoca by fluorescent-labeled primers and development of micropropagation protocol for its conservation. Int. J. Appl. Agri. Res., 2017, 12, 137-151.

38. Mollik, M. A. H., Hossan, M. S., Paul, A. K., Taufiq-Ur-Rahman, Jahan, R. and Rahmatullah, M., A comparative analysis of medicinal plants used by folk medicinal healers in three districts of Bangladesh and inquiry as to mode of selection of medicinal plants. Ethnobotany Res. Appl., 2010, 8,195-218.

39. Mukherjee, T., Chowdhury, S., Kumar, A., Majumder, H. K., Jaisankar, P. and Mukhopadhyay, S., Saracoside: a new lignan glycoside from Saraca indica, a potential inhibitor of DNA topoi- somerase IB. Nat. Prod. Commun. 2012, 7, 767-769.

40. Nadakarni, K. M., The Indian Materia Medica, Popular Book Depot, Bombay, 1957, 3rd edn, p. 1075.

41. Nag, D., Ghosh, M. and Mukherjee, A., Antimutagenic and geno- protective effects of Saraca asoca bark extract. Toxicol. Indian Health, 2013, 8, 696-703.

42. Pai SR, Nimbalkar MS, Pawar NV, Dixit GB (2011) Optimization of extraction techniques and quantification of betulinic acid (BA) by RP-HPLC method from Ancistrocladusheyneanus Wall. Ex Grah.Ind Crops Prod 34:1458-1464

43. Pal, S. C., Maiti, A. P., Chatterjee, B. P. and Nandy, A., Antibac-terial activity of flowers and flower buds of Saraca indica. Ind. J. Med. Res., 1985, 82, 188-189.

44. Pal, T. K., Bhattacharyya, S. and Dey, A., Evaluation of antioxi- dant activities of flower extract (fresh and dried) of Saraca indica grown in West Bengal. Int. J. Curr.Microbiol. Appl. Sci., 2014, 3, 251-259.

45. Panchawat, S. and Sisodia, S. S., In vitro antioxidant activity of Saraca asoca Roxb. de Wilde stem bark extracts from various ex- traction processes. Asian J. Pharm. Clin. Res., 2010, 3, 231-233.

46. Pandey, A. K., Ojha, V., Yadav, S. and Sahu, S. K., Phytochemi- cal evaluation and radical scavenging activity of Bauhinia varie- gata, Saraca asoca and Terminalia arjuna barks. Res. J. Phytochem., 2011, 5, 8997.

47. Paranthaman, M., Usha Kumari R., Laxmi Narayan, N. and Sivasubramaniam, K., Morphological characterization and In vitro callus induction in Ashoka [Saraca asoca (Roxb.) De Wilde.] a vulnerable medicinal tree. Int. J. Agri. Innov. Res., 2017, 5, 743-747.

48. Pawar N, Pai S, Nimbalkar M, Dixit G (2011) RP-HPLC analysis of phenolic antioxidant compound 6-gingerol from different ginger cultivars. Food Chem 126:1330-1336 
49. Pradhan, P., Joseph, L., Gupta, V., Chulet, R., Arya, H., Verma, R. and Bajpai, A., Saraca asoca (Ashoka): a review. J. Chem. Pharm. Res., 2009, 1, 62-71.

50. Prajapati, N. D., Purohit, S. S., Sharma, A. K. and Kumar, T. A., Hand book of medicinal plants, $1^{\text {st }}$ ed., Agrobias, India, 2003, 460-461.

51. Prathapan, A., Nampoothiri, S. V., Mini, S. and Raghu, K. G., Antioxidant, antiglycation and inhibitory potential of Saraca asoca flowers against the enzymes linked to type 2 diabetes and LDL oxidation. Eur. Rev. Med. Pharmacol. Sci., 2012, 16, 57-65.

52. Preethi, F. and Krishnakumar, K., Anti-inflammatory activity of the barks of Saraca indica Linn. Pharmacology Online, 2011, 2, 657-662.

53. Preeti, B., Bharti, A., Sharma, A. and Vishwabhan, S., A review on Saraca indica plant. Int. Res. J. Pharm., 2012, 3, 80-84.

54. Purohit, S. S. and Vyas, S. P., Medicinal Plant cultivation. $1^{\text {st }}$ ed., Agrobias, India, 2004, 514-516.

55. Rangari, V. D. Pharmacognosy and Phytochemistry. Vol. II, 2 $2^{\text {nd }}$ ed., Career Publication, Nashik, 2012, 269271.

56. Rastogi, R. P. and Mehrotra, B. N., Compendium of Indian Medicinal Plants. Vol. II, Central Drug Research Institute, Lucknow \& National Institute of Science Communication \& Information Resources, New Delhi, 1999, 611-612.

57. Sadhu, S. K., Khatun, A., Phattanawasin, P., Ohtsuki, T. and Ishibashi, M., Lignan glycosides and flavonoids from Saraca asoca with antioxidant activity. J. Nat. Med., 2007, 61, 480-482.

58. Saha J, Mukherjee S, Gupta K, Gupta B (2013) High-performance thin-layer chromatographic analysis of antioxidants present in different parts of Saraca asoca (Roxb.) de Wilde. J Pharm Res 7:798-803

59. Saha, J., Mitra, T., Gupta, K. and Mukherjee, S., Phytoconstitu- entsand HPTLC analysis in Saraca asoca (roxb.) Wilde. Int. J. Pharm. Pharm. Sci., 2012, 4,96-99.

60. Saha, J., Mukherjee, S., Gupta, K. and Gupta, B., High- performance thin-layer chromatographic analysis of antioxidants present in different parts of Saraca asoca (Roxb.) de Wilde. J. Pharm. Res., 2013, 1-6.

61. Saini, A., Hegde, S., Hegde, H. S., Kholkute, S. D. and Roy, S., Assessment of genetic diversity of Saraca asoca (Roxb.) De Wilde: a commercially important, but endangered, forest tree species in Western Ghats, India. New Zealand J.Forest. Sci., 2018, 48, 17-28.

62. Samee, W. and Vorarat, S., Simultaneous determination of gallic acid, catechin, rutin, ellagic acid and quercetin in flower extracts of Michelia alba, Caesalpiniapulcherrima and Nelumbonucifera by HPLC. Thai Pharm. Health Sci. J., 2007, 2, 131-137.

63. Saravanan, S., Babu, N. P., Pandikumar, P. and Ignacimuthu, S., Therapeutic effect of Saraca asoca (Roxb.) Wilde on lysosomal enzymes and collagen metabolism in adjuvant induced arthritis. Inflammopharmacol. 2011, 19, 317-325.

64. Sarojini, N., Manjari, S. A. and Chandrakanti, C., Correlation between phytochemical screening and some biological activity using plant extracts. Int. J. Res. Ayurveda Pharm., 2011, 4, 1343-1348.

65. Sarojini, N., Manjari, S. A. and Kanti, C. C., Phytochemical screening and anti-helminthic activity study of Saraca indica leaves extract. Int. Res. J. Pharm., 2011, 2, 194-197.

66. Sarojini, N., Manjari, S. A. and Kanti, C. C., Phytochemical screening and antibacterial activity study of Saraca indica leaves extract. Int. Res. J. Pharm., 2011, 2, 176-179.

67. Sasmal, S., Majumdar, S., Gupta, M., Mukherjee, A. and Mukher- jee, P. K., Pharmacognostical, phytochemical and pharmacologi- cal evaluation for the antipyretic effect of the seeds of Saraca asoca Roxb. Asian Pac. J. Trop. Biomed., 2012, 2, 782-786.

68. Satyavati, G. V., Prasad, D. N., Sen, S. P. and Das, P. K., Oxyto- cic activity of a pure phenolic glycoside (P2) from Saracaindica Linn (Ashoka): a short communication. Indian J.Med. Res., 1970, 58, 660-663.

69. Schlag, E.M., McIntosh, M.S., 2013. The relationship between genetic and chemotypic diversity in American ginseng (Panaxquinquefolius L.).Phytochemistry 93, 96-104. Senapati, S.K., Das, G.K., Aparajita, S., Rout, G.R., 2012. Assessment of genetic variability in the Asoka tree of India. Biodiversity 13, 16-23

70. Shelar, D. B., Shirote, P. J. and Naikwade, N. S., Anti- inflammatory activity and brine shrimps lethality test of Saraca indica (Linn.) leaves extract. J. Pharm. Res., 2010, 3, 2004-2006.

71. Shirin, F., Parihar, N. S. and Shah, S. N., Effect of Nutrient Media and $\mathrm{KNO}_{3}$ on in Vitro Plant Regeneration in Saraca asoca (Roxb.) Willd. American J. Plant Sci., 2015, 6, 3282-3292.

72. Shirolkar, A., Gahlaut, A., Chhillar, A. K. and Dabur, R., Quanti- tative analysis of catechins in Saraca asoca and correlation with antimicrobial activity. J. Pharm. Anal., 2013, 3, 421-428.

73. Singh, A., Singh, S., Sarma, B. K., Singh, U. P., Srivastava, R. and Singh, K. P., Internet J. Altern. Med., 2009, $6,1-20$. 
74. Somani, G. and Sathaye, S., Bioactive fraction of Saracaindica prevents diabetes induced cataractogenesis: an aldose reductase inhibitory activity. Pharmacogn. Mag., 2015, 11, 102-110.

75. Sumangala, R. C., Shaanker, R. U., Dayanandan, S., Vasudeva, R. and Ravikanth, G., Identification of novel microsatellite markers for Saraca asoca, a medicinally important tree species in India. J. Genet., 2013, 92, 9395.

76. Sumangala, R.C., Rosario, S., Charles, B., Ganesh, D., Ravikanth, G., 2017. Identifying conservation priority sites for Saraca asoca: an important medicinal plant using ecological Niche models.Indian For. 143, 531-536.

77. Sumangala, R.C., Shaanker, R.U., Dayanandan, S., Vasudeva, R., Ravikanth, G., 2016. Identification of novel microsatellite markers for Saraca asoca, a medicinally important tree species in India. J. Genet. 93, 93-95.

78. Swamy, A. H. M. V., Patel, U. M., Koti, B. C., Gadad, P. C., Patel, N. L. and Thippeswamy, A. H. M., Cardioprotective effect of Saracaindica against cyclophosphamide induced cardiotoxic- ity in rats: a biochemical, electrocardiographic and histopa- thological study. Indian J. Pharmacol., 2013, 45, 44-48.

79. Thakur R. S., Puri H. S. and Akhtar Husain 1989 Major medicinal plants of India, pp. 391-394. Central Institute of Medicinal and Aromatic Plants, Lucknow, India.

80. Urumarudappa SKJ, Gogna N, Newmaster SG, Venkatarangaiah K, Subramanyam R, Saroja SG, Gudasalamani R, Dorai K, Ramanan US (2016) DNA barcoding and NMR spectroscopybased assessment of species adulteration in the raw herbal trade of Saraca asoca (Roxb.) Willd, an important medicinal plant.Int J Legal Med 130:1457-1470

81. Varaprasad, N. et al., Antipyretic activity of methanolic extract of Saraca asoca (roxb.) de Wild leaves. Int. J. Pharm. Res. Dev., 2011, 3, 202-207.

82. Verma, A., Jana, G. K., Chakraborty, R., Sen, S., Sachan, S. and Mishra, A., Analgesic activity of various leaf extracts of Saraca indica Linn. Der Pharm. Let., 2010, 2, 352-357.

83. Verma, A., Jana, G. K., Sen, S., Chakraborty, R., Sachan, S. and Mishra, A., Pharmacological evaluation of Saraca indica leaves for central nervous system depressant activity in mice. J. Pharm. Sci. Res., 2010, 2(6), 338-343.

84. Yadav, G., Garg, V. K., Thakur, N. and Khare, P., Locomotor Activity of methanolic extract of Saraca indica bark. Adv. Biol. Res., 2013, 7, 1-3.

85. Yadav, N. K. et al., Saraca indica bark extract shows in vitro an- tioxidant, antibreast cancer activity and does not exhibit toxicological effects. Oxid. Med. Cell. Longev. 2015, doi: 10.1155/ 2015/205360.

86. Younsi, F., Rahali, N., Mehdi, S., Boussaid, M., Messaoud, C., 2018. Relationship between chemotypic and genetic diversity of natural populations of Artemisia herba-alba Asso growing wild in Tunisia.Phytochemistry $148,48-56$. 